\title{
GROWTH FROM BIRTH TO ADULT LIFE OF 442 NEWCASTLE UPON TYNE CHILDREN
}

\author{
F. J. W. MILLER, W. Z. BILLEWICZ AND A. M. THOMSON \\ Department of Child Health, University of Newcastle upon Tyne and \\ MRC Reproduction and Growth Unit, Newcastle upon Tyne
}

There have been few longitudinal studies of human growth from birth to adult life, and those that have been reported have been on samples that may have been highly selected. The 'Thousand Families in Newcastle upon Tyne' study was originally based on all of the 1,142 babies born in the city during May and June 1947 (Spence, Walton, Miller, and Court, 1954; Miller, Court, Walton, and Knox, 1960). The families were seen regularly until 1962, when the children reached age 15 and most of them left school. Thereafter, contact was discontinued except for a limited study of work-experience among 18-year-old boys, and a follow-up at the same age of maladjusted children and a control sample. The primary purpose of the Thousand Families study was to measure the frequency and extent of disease and disablement in a representative sample of the City's children' (Spence et al., 1954). Measurements of growth were more or less incidental, but birth weights, measured by the maternity services, were recorded on the survey archives; and the children were measured at ages $3,5,9,13,14$, and 15. Age at menarche in girls was noted, but there are no records of the timing of puberty in boys.

In 1968, it was decided to trace and re-measure as many of the 'children' as possible. A grant from the Medical Research Council to F. J. W. M. made it possible to arrange the necessary field work during the spring of 1969 when the subjects were nearly 22 years of age.

\section{Materials and Methods}

The original cohort consisted of 1,142 infants from 1,132 families. At the end of one year, the number of families still actively cooperating was 967 , losses being mainly through migration (127 families) and death ( 44 children). At the end of five years, 847 children were still under regular observation, and by age 15 , about 750 children remained accessible. A preliminary ascertainment study six years later (1968) showed that nearly half of the sample at 15 years of age was probably still resident in Newcastle upon Tyne. In the actual follow-up, a total of 442 subjects, 201 males and 241 females, was traced and measured, i.e., nearly $60 \%$ of the 15-year-old sample. The 'successes' included several individuals who, though no longer resident in Newcastle, got to hear of the follow-up and offered their co-operation when visiting the city. An increased success-rate could no doubt have been achieved by adopting intensive follow-up methods to locate and measure individuals who were not readily accessible in and around Newcastle; but the effort would have been costly and was judged to be not worth while.

All accessible subjects were visited at home by a health visitor, who completed a form giving inforo mation on marital status, employment history educational level, hospital admissions, and housing Weight in indoor clothing was measured to the nearest pound on high-quality bathroom-type scales (Salters' type 209) and height without shoes was recorded to the nearest $0.1 \mathrm{~cm}$ by means of a portable device incorporating a steel tape in a bracket that can be placed on a vertical surface with an arm in contact with the subject's head, the distance from the arm to the floor being measured.

Birth weights were taken from domiciliary midwifery service or maternity hospital records. Heights and weights at (approximate) ages 3,5 , $9,13,14$, and 15 years were measured in child welfare clinics or by the school health service. Measurements at ' 5 years' were obtained in schools at an average of 5.8 years. Little information is available about the accuracy of these earlier records; but since the children were known to be participating in a special survey it is possible that more care than usual was taken over measurements.

It is not possible to assess the extent to which the 442 subjects traced in 1969 represented the original complete sample. In terms of parents' social class and of weight and height at age 15, those traced and those not traced were similar. Thus, while we cannot say that the sample investigated at age 22 was fully representative of the original cohort, we can conclude that there is no evidence of serious bias. 
RESULTS

Data are necessarily presented in terms of the ages at which observations were made and recorded.

Occupation and Social Class

The social class of children's parents was recorded at ages 5 and 15. Cross-tabulation showed that $82 \%$ of individuals were in the same class (combining $\mathrm{I}+\mathrm{II}$ and IV + V) at each age. For present purposes, parents' social class has been defined as that at age 5; in a small minority, where the information was not available, social class at age 15 has been utilized.

The standard social classes were not appropriate for classifying the occupations of the subjects themselves, about half of whom were females. We therefore distinguished five categories: professional, clerical, distributive, skilled manual, and unskilled manual. Since the subjects were beginning their careers (at age 22) it seemed reasonable to think in terms of prospects rather than of current socioeconomic status: students were therefore allocated to the professional category.

Table I shows the distributions of parents' social classes and subjects' occupations. When the parents belonged to classes I and II, about half of the male and the female subjects were in professional jobs; but, of the remainder, males were distributed fairly equally between clerical, distributive, and skilled manual occupations, and nearly all females were in clerical posts. When the parents were in social classes III, IV, or V, about $18 \%$ of the boys, and about $10 \%$ of the girls, took up professional occupations. About half the girls took up clerical jobs, irrespective of parents' social class.

Job mobility (number of posts held) was lowest in the professional group and highest in the distributive and unskilled manual workers. The differences are doubtless influenced by the fact that subjects with longer vocational training had less time to change
TABLE I

OCCUPATION OF SUBJECTS BY SOCIAL CLASS OF THEIR PARENTS

\begin{tabular}{|c|c|c|c|c|}
\hline \multirow{2}{*}{$\begin{array}{l}\text { Subjects' } \\
\text { Occupation }\end{array}$} & \multicolumn{4}{|c|}{ Social Class of Parents* } \\
\hline & $\mathbf{I}+\mathbf{I I}$ & III & $\mathbf{I V}+\mathbf{V}$ & All \\
\hline $\begin{array}{ll}\text { Males: } \dagger & \\
\text { Professional } & \ldots \\
\text { Clerical } & \ldots \\
\text { Distributive } & \ldots \\
\text { Skilled manual } & \ldots \\
\text { Unskilled manual } & . .\end{array}$ & $\begin{array}{r}12 \\
4 \\
4 \\
5 \\
-\end{array}$ & $\begin{array}{r}24 \\
19 \\
3 \\
41 \\
18\end{array}$ & $\begin{array}{r}6 \\
5 \\
3 \\
40 \\
11\end{array}$ & $\begin{array}{l}42 \\
28 \\
10 \\
86 \\
29\end{array}$ \\
\hline All & 25 & 105 & 65 & 195 \\
\hline $\begin{array}{l}\text { Females: } \\
\text { Professional } \\
\text { Clerical . } \\
\text { Distributive } \\
\text { Skilled manual } \\
\text { Unskilled manual }\end{array}$ & $\begin{array}{r}9 \\
8 \\
-1 \\
-\end{array}$ & $\begin{array}{r}20 \\
82 \\
9 \\
8 \\
22\end{array}$ & $\begin{array}{r}2 \\
41 \\
10 \\
2 \\
22\end{array}$ & $\begin{array}{r}31 \\
131 \\
19 \\
11 \\
44\end{array}$ \\
\hline All & 18 & 141 & 77 & 236 \\
\hline
\end{tabular}

*Parents' class of 2 male and 5 female subjects not stated. † Male subjects' occupation in 4 cases not stated.

jobs. Unemployment was not a serious problem in 1969 ; about $6 \%$ of the males and $4 \%$ of the females had been out of work for six months or more since leaving school.

\section{FAMILY BACKGROUND}

Table II shows the distributions of family size, birth rank, and sex of 431 subjects at age 15 .

The proportion of subjects married at age 22 was lowest for those in the professional occupations$17.5 \%$ of men and $16.1 \%$ of women. Overall, $31.3 \%$ of men and $54.8 \%$ of women were married.

Weight and Height: Effects of Age, Social Class, Birth Rank, and Birth Weight

Birth weights had been recorded for all the 442 subjects weighed and measured at age 22 , but no birth lengths. The intermediate measurements per subject (at ages $3,5,9,13,14$, and 15 years) were complete in $55 \%$ of cases: in $30 \%$ one measurement was missing and in $15 \%$ more than one measurement.

TABLE II

DISTRIBUTION OF SUBJECTS BY SEX, BIRTH RANK, AND FAMILY SIZE AT AGE 15 (6 MALES AND 5 FEMALES, ALL TWINS, HAVE BEEN EXCLUDED)

\begin{tabular}{|c|c|c|c|c|c|c|c|c|c|c|c|c|}
\hline \multirow{3}{*}{$\begin{array}{l}\text { Family Size or } \\
\text { Birth Rank }\end{array}$} & \multicolumn{6}{|c|}{ Family Size at 15 Years } & \multicolumn{6}{|c|}{ Birth Rank } \\
\hline & \multicolumn{2}{|c|}{ Males } & \multicolumn{2}{|c|}{ Females } & \multicolumn{2}{|c|}{ Both } & \multicolumn{2}{|c|}{ Males } & \multicolumn{2}{|c|}{ Females } & \multicolumn{2}{|c|}{ Both } \\
\hline & No. & $\%$ & No. & $\%$ & No. & $\%$ & No. & $\%$ & No. & $\%$ & No. & $\%$ \\
\hline \multirow[t]{2}{*}{$\begin{array}{l}1 \\
2 \\
3 \\
4 \\
5 \\
6 \\
7+\end{array}$} & $\begin{array}{l}27 \\
54 \\
42 \\
29 \\
15 \\
17 \\
11\end{array}$ & $\begin{array}{r}13 \cdot 8 \\
27 \cdot 7 \\
21 \cdot 5 \\
14 \cdot 9 \\
7 \cdot 7 \\
8 \cdot 7 \\
5 \cdot 6\end{array}$ & $\begin{array}{l}28 \\
67 \\
61 \\
44 \\
12 \\
14 \\
20\end{array}$ & $\begin{array}{r}11 \cdot 9 \\
28 \cdot 4 \\
25 \cdot 8 \\
14 \cdot 4 \\
5 \cdot 1 \\
5 \cdot 9 \\
8 \cdot 5\end{array}$ & $\begin{array}{r}55 \\
121 \\
103 \\
63 \\
27 \\
31 \\
31\end{array}$ & $\begin{array}{r}12 \cdot 8 \\
28 \cdot 1 \\
23 \cdot 9 \\
14 \cdot 6 \\
6 \cdot 3 \\
7 \cdot 2 \\
7 \cdot 2\end{array}$ & $\begin{array}{r}82 \\
61 \\
24 \\
15 \\
6 \\
3 \\
4\end{array}$ & $\begin{array}{r}42 \cdot 1 \\
31 \cdot 3 \\
12 \cdot 3 \\
7 \cdot 7 \\
3 \cdot 1 \\
1 \cdot 5 \\
2 \cdot 1\end{array}$ & $\begin{array}{r}95 \\
65 \\
45 \\
10 \\
6 \\
6 \\
9\end{array}$ & $\begin{array}{r}40 \cdot 3 \\
27 \cdot 5 \\
19 \cdot 1 \\
4 \cdot 2 \\
2.5 \\
2 \cdot 5 \\
3 \cdot 8\end{array}$ & $\begin{array}{r}177 \\
126 \\
69 \\
25 \\
12 \\
9 \\
13\end{array}$ & $\begin{array}{r}41 \cdot 1 \\
29 \cdot 2 \\
16 \cdot 0 \\
5 \cdot 8 \\
2 \cdot 8 \\
2 \cdot 1 \\
3 \cdot 0\end{array}$ \\
\hline & 195 & 100 & 236 & 100 & 431 & 100 & 195 & 100 & 236 & 100 & 431 & 100 \\
\hline
\end{tabular}


TABLE III

MEAN WEIGHTS AND HEIGHTS ( $\overline{\mathrm{x}}$ ) AND THEIR STANDARD DEVIATIONS $(\sigma)$ BY SEX AT VARIOUS AGES: NUMBERS OF SUBJECTS IN PARENTHESES

\begin{tabular}{|c|c|c|c|c|c|c|c|c|c|c|}
\hline & & & Birth & $3 \mathrm{yr}$ & $5 \mathrm{yr}$ & $9 \mathrm{yr}$ & $13 \mathrm{yr}$ & $14 \mathrm{yr}$ & $15 \mathrm{yr}$ & $22 \mathrm{yr}$ \\
\hline $\begin{array}{c}\text { Weight }(\mathbf{k g}) \\
\text { Males } \overline{\mathrm{x}} \\
\begin{array}{c}\sigma \\
\text { Females } \bar{x} \\
\sigma\end{array}\end{array}$ & $\begin{array}{l}. . \\
. . \\
. .\end{array}$ & $\begin{array}{l}. . \\
. . \\
. \\
. .\end{array}$ & $\begin{array}{c}3.46 \\
(201) \\
0.57 \\
3.33 \\
(241) \\
0.50\end{array}$ & $\begin{array}{c}14 \cdot 71 \\
(156) \\
1 \cdot 70 \\
14 \cdot 27 \\
(182) \\
1 \cdot 63\end{array}$ & $\begin{array}{c}19 \cdot 53 \\
(185) \\
2 \cdot 21 \\
18 \cdot 86 \\
(200) \\
2 \cdot 20\end{array}$ & $\begin{array}{c}27 \cdot 09 \\
(197) \\
3 \cdot 39 \\
26 \cdot 78 \\
(237) \\
4 \cdot 18\end{array}$ & $\begin{array}{c}40 \cdot 98 \\
(199) \\
7 \cdot 58 \\
43 \cdot 24 \\
(235) \\
8 \cdot 57\end{array}$ & $\begin{array}{c}47 \cdot 23 \\
(175) \\
9 \cdot 16 \\
48 \cdot 54 \\
(216) \\
8 \cdot 70\end{array}$ & $\begin{array}{c}52 \cdot 88 \\
(182) \\
8 \cdot 72 \\
51 \cdot 13 \\
(202) \\
7 \cdot 85\end{array}$ & $\begin{array}{c}69 \cdot 72 \\
(201) \\
9 \cdot 89 \\
57 \cdot 07 \\
(241) \\
9 \cdot 36\end{array}$ \\
\hline $\begin{array}{c}\text { Height }(\mathrm{cm}) \\
\text { Males } \overline{\mathrm{x}} \\
\sigma \\
\text { Females } \overline{\mathrm{x}} \\
\sigma\end{array}$ & $\begin{array}{l}. . \\
. \\
. .\end{array}$ & $\begin{array}{l}. . \\
. . \\
. .\end{array}$ & - & $\begin{array}{r}93 \cdot 0 \\
(153) \\
4 \cdot 1 \\
92 \cdot 4 \\
(181) \\
3 \cdot 7\end{array}$ & $\begin{array}{c}110.0 \\
(185) \\
5.1 \\
109.6 \\
(199) \\
5.0\end{array}$ & $\begin{array}{r}128 \cdot 8 \\
(197) \\
5.8 \\
127.7 \\
(237) \\
6.1\end{array}$ & $\begin{array}{r}148.9 \\
(199) \\
7.7 \\
150.7 \\
(235) \\
7.0\end{array}$ & $\begin{array}{r}155.9 \\
(175) \\
8.2 \\
155.5 \\
(215) \\
6.2\end{array}$ & $\begin{array}{r}163 \cdot 1 \\
(182) \\
7 \cdot 6 \\
158 \cdot 0 \\
(202) \\
5.9\end{array}$ & $\begin{array}{r}172.9 \\
(201) \\
6 \cdot 8 \\
160.3 \\
(239) \\
6.0\end{array}$ \\
\hline
\end{tabular}

Table III gives mean weights and heights at each age for males and for females, together with standard deviations. At age 13 girls have overtaken boys, no doubt due to their earlier maturation, but by age 15 males are clearly taller and heavier than females, and the differential is much larger at age 22.

Table IV shows mean weights and heights for each sex, by parents' social class. Females have a well-marked social gradient in weight from age 5 onwards, but among males the gradient is small or absent. With height, on the other hand, males show an obvious social class gradient at all ages, whereas the equivalent gradient in females has disappeared at ages 15 and 22.

As would be expected, similar social class differentials are shown when the data are examined on the basis of increments between one age and the next.

Table $\mathrm{V}$ shows mean weights and heights by birth rank. With small numbers in each cell, the trends are even more irregular than those by social class, but there is obviously a tendency for weight and height to become less with increasing birth rank, particularly in higher age groups. The marked sex difference in the trend of weight by social class does not reappear by birth order; on the other hand, the trend of height by birth rank seems to be more consistent in females than in males, whereas the opposite was true of the trends by social class.

Trends by size of family are not shown. They are very similar to those by birth rank.

In view of suggestions that the effects of early growth retardation may be irreversible, it is of interest to examine the correlations between birth weight and size at subsequent ages. Figures 1 and 2 show mean weights and heights in subjects by birth weight. It is clear that the ranking of average height and weight by birth weight tends to persist throughout growth and is still present at age 22
TABLE IV

MEAN WEIGHTS AND HEIGHTS BY AGE, SEX, AND \begin{tabular}{l} 
PARENTS' SOCIAL CLASS AT AGE 5 \\
\hline
\end{tabular}

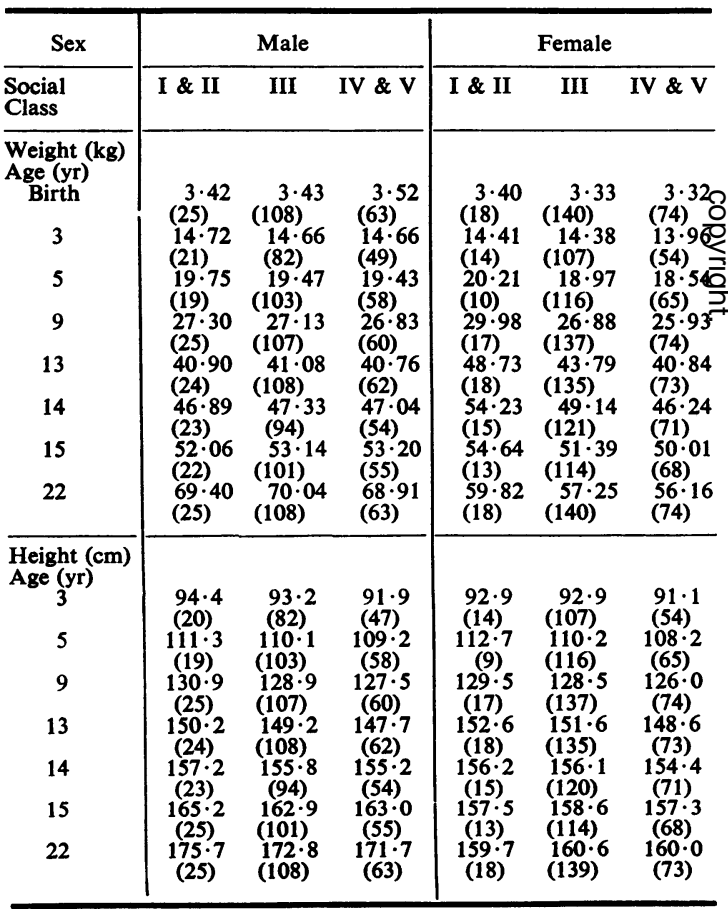

when growth has ceased. Table VI gives the information in a different way. A correlation coefficient of around 0.20 between birth weight on the one hand and weight and height on the other persists through school ages into adult life.

\section{WEIGHT-FOR-HEIGHT}

Weight-for-height gives a crude index of relative obesity or thinness, most easily expressed as the 
TABLE V

MEAN WEIGHTS AND HEIGHTS BY BIRTH RANK, SEX, AND AGE

\begin{tabular}{|c|c|c|c|c|c|c|c|c|c|c|c|}
\hline \multirow{2}{*}{$\begin{array}{l}\text { Sex } \\
\text { Birth Rank }\end{array}$} & & \multicolumn{5}{|c|}{ Male } & \multicolumn{5}{|c|}{ Female } \\
\hline & & 1 & 2 & 3 & 4 & $5+$ & 1 & 2 & 3 & 4 & $5+$ \\
\hline $\begin{array}{r}\text { Weight (kg) } \\
\text { Age (yr) } \\
\text { Birth } \\
3 \\
5 \\
9 \\
15 \\
22\end{array}$ & $\begin{array}{l}\cdots \\
\ldots \\
\cdots \\
\cdots \\
\cdots \\
\cdots\end{array}$ & $\begin{array}{l}3 \cdot 29 \\
(82) \\
14 \cdot 6 \\
(66) \\
19 \cdot 4 \\
(78) \\
27 \cdot 3 \\
(81) \\
53 \cdot 5 \\
(74) \\
70 \cdot 0 \\
(82)\end{array}$ & $\begin{array}{l}3 \cdot 50 \\
(61) \\
14 \cdot 8 \\
(47) \\
19 \cdot 8 \\
(53) \\
27 \cdot 4 \\
(59) \\
53 \cdot 3 \\
(55) \\
70 \cdot 5 \\
(61)\end{array}$ & $\begin{array}{l}3 \cdot 81 \\
(29) \\
15 \cdot 4 \\
(18) \\
19 \cdot 9 \\
(24) \\
27 \cdot 3 \\
(23) \\
52 \cdot 9 \\
(22) \\
69 \cdot 6 \\
(24)\end{array}$ & $\begin{array}{l}3 \cdot 68 \\
(15) \\
14 \cdot 2 \\
(12) \\
19 \cdot 1 \\
(12) \\
25 \cdot 9 \\
(15) \\
51 \cdot 3 \\
(12) \\
71 \cdot 4 \\
(15)\end{array}$ & $\begin{array}{l}3 \cdot 95 \\
(13) \\
14 \cdot 6 \\
(7) \\
19 \cdot 4 \\
(13) \\
26 \cdot 2 \\
(13) \\
50 \cdot 3 \\
(13) \\
65 \cdot 3 \\
(13)\end{array}$ & $\begin{array}{l}3 \cdot 21 \\
(95) \\
14 \cdot 5 \\
(79) \\
19 \cdot 2 \\
(77) \\
27 \cdot 7 \\
(94) \\
52 \cdot 1 \\
(76) \\
58 \cdot 1 \\
(95)\end{array}$ & $\begin{array}{l}3 \cdot 40 \\
(65) \\
14 \cdot 5 \\
(48) \\
19 \cdot 1 \\
(55) \\
26 \cdot 9 \\
(65) \\
51 \cdot 8 \\
(56) \\
57 \cdot 8 \\
(65)\end{array}$ & $\begin{array}{l}3 \cdot 39 \\
(45) \\
13 \cdot 7 \\
(32) \\
18 \cdot 0 \\
(36) \\
25 \cdot 3 \\
(43) \\
48 \cdot 8 \\
(37) \\
55 \cdot 4 \\
(45)\end{array}$ & $\begin{array}{l}3 \cdot 44 \\
(10) \\
14 \cdot 3 \\
(8) \\
19 \cdot 1 \\
(10) \\
26 \cdot 3 \\
(10) \\
53 \cdot 4 \\
(10) \\
57 \cdot 2 \\
(10)\end{array}$ & $\begin{array}{l}3 \cdot 67 \\
(21) \\
14 \cdot 2 \\
(10) \\
18 \cdot 4 \\
(17) \\
26 \cdot 0 \\
(20) \\
49 \cdot 0 \\
(20) \\
54 \cdot 5 \\
(21)\end{array}$ \\
\hline $\begin{array}{r}\text { Height (cm) } \\
\text { Age (yr) } \\
3 \\
5 \\
9 \\
15 \\
22\end{array}$ & $\cdots$ & $\begin{array}{c}93 \cdot 2 \\
(63) \\
110 \cdot 5 \\
(77) \\
129 \cdot 5 \\
(81) \\
164 \cdot 0 \\
(74) \\
172 \cdot 9 \\
(82)\end{array}$ & $\begin{array}{c}93 \cdot 3 \\
(47) \\
110 \cdot 1 \\
(54) \\
129 \cdot 2 \\
(59) \\
162 \cdot 8 \\
(55) \\
173 \cdot 5 \\
(1)\end{array}$ & $\begin{array}{c}94 \cdot 3 \\
(18) \\
109 \cdot 8 \\
(24) \\
128 \cdot 2 \\
(23) \\
162 \cdot 9 \\
(22) \\
174 \cdot 2 \\
(24)\end{array}$ & $\begin{array}{c}91 \cdot 7 \\
(12) \\
109 \cdot 2 \\
(12) \\
127 \cdot 0 \\
(15) \\
163 \cdot 1 \\
(12) \\
172 \cdot 0 \\
(15)\end{array}$ & $\begin{array}{c}91 \cdot 6 \\
(7) \\
109 \cdot 4 \\
(13) \\
127 \cdot 1 \\
(13) \\
160 \cdot 7 \\
(13) \\
172 \cdot 2 \\
(13)\end{array}$ & $\begin{array}{c}93 \cdot 1 \\
(28) \\
110 \cdot 9 \\
(77) \\
128 \cdot 9 \\
(94) \\
159 \cdot 0 \\
(76) \\
160 \cdot 9 \\
(95)\end{array}$ & $\begin{array}{c}92 \cdot 4 \\
(48) \\
109 \cdot 7 \\
(55) \\
128 \cdot 1 \\
(65) \\
158 \cdot 4 \\
(56) \\
161 \cdot 0 \\
(64)\end{array}$ & $\begin{array}{c}91 \cdot 4 \\
(32) \\
107 \cdot 5 \\
(35) \\
126 \cdot 3 \\
(43) \\
158 \cdot 1 \\
(37) \\
160 \cdot 1 \\
(45)\end{array}$ & $\begin{array}{c}91 \cdot 4 \\
(8) \\
109 \cdot 5 \\
(10) \\
126 \cdot 9 \\
(10) \\
156 \cdot 6 \\
(10) \\
158 \cdot 7 \\
(10)\end{array}$ & $\begin{array}{c}90 \cdot 4 \\
(10) \\
107 \cdot 8 \\
(17) \\
124 \cdot 7 \\
(20) \\
154 \cdot 8 \\
(20) \\
156 \cdot 7 \\
(20)\end{array}$ \\
\hline
\end{tabular}

TABLE VI COEFFICIENTS OF CORRELATIONS BETWEEN BIRTH 음

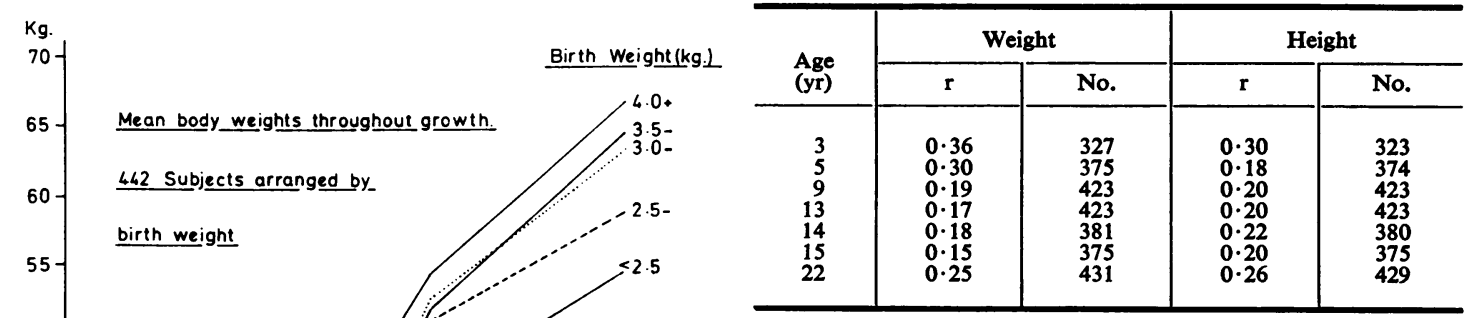
CORQELT HE

\begin{tabular}{|c|c|c|c|c|}
\hline \multirow{2}{*}{$\begin{array}{l}\text { Age } \\
\text { (yr) }\end{array}$} & \multicolumn{2}{|c|}{ Weight } & \multicolumn{2}{|c|}{ Height } \\
\hline & $\mathbf{r}$ & No. & $\mathbf{r}$ & No. \\
\hline $\begin{array}{r}3 \\
5 \\
9 \\
13 \\
14 \\
15 \\
22\end{array}$ & $\begin{array}{l}0 \cdot 36 \\
0.30 \\
0 \cdot 19 \\
0 \cdot 17 \\
0 \cdot 18 \\
0 \cdot 15 \\
0 \cdot 25\end{array}$ & $\begin{array}{l}327 \\
375 \\
423 \\
423 \\
381 \\
375 \\
431\end{array}$ & $\begin{array}{l}0.30 \\
0.18 \\
0.20 \\
0.20 \\
0.22 \\
0.20 \\
0.26\end{array}$ & $\begin{array}{l}323 \\
374 \\
423 \\
423 \\
380 \\
375 \\
429\end{array}$ \\
\hline
\end{tabular}

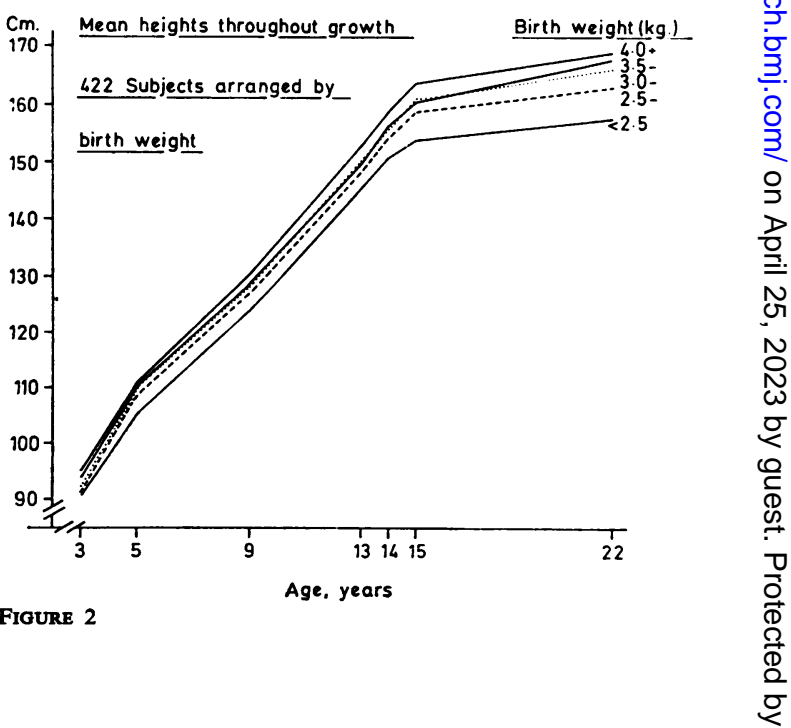

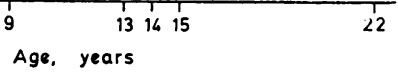

FIGURE 
TABLE VII

COEFFICIENTS OF CORRELATION (r) BETWEEN WEIGHTFOR-HEIGHT RATIOS* AT VARIOUS AGES (BOTH SEXES): NUMBERS OF SUBJECTS IN PARENTHESES

\begin{tabular}{r|c|c|c|c|c}
\hline $\begin{array}{c}\text { Age } \\
\text { (yr) }\end{array}$ & 9 & 13 & 14 & 15 & 22 \\
\hline & 5 & $0.59(369)$ & $0.48(368)$ & $0.46(332)$ & $0.49(338)$ \\
9 & - & $0.71(414)$ & $0.66(374)$ & $0.58(369)$ & $0.45(372)$ \\
13 & - & - & $0.92(374)$ & $0.83(371)$ & $0.64(430)$ \\
14 & - & - & - & $0.91(343)$ & $0.67(378)$ \\
15 & - & - & - & - & $0.66(373)$ \\
\hline
\end{tabular}

* Observed weight as percentage of standard weight-for-height.

percentage of observed weight to a standard weight for height at a given age. The standards used for children aged 5 to 15 were those of the U.S.A. Interdepartmental Committee on Nutrition for National Defense (ICNND, 1963) and for adults those of Kemsley, Billewicz, and Thomson (1962). Since two different standards have been employed, longitudinal comparisons involving a change of standard must be interpreted with caution.

For what it is worth, it seems that the males in the present samples were slightly overweight, on average, compared with the standards, the observed median weights ranging from 103 to $109 \%$ of standard at various ages. On the other hand, girls were very nearly of standard weight-for-height.

Table VII gives the coefficients of correlation between weight-for-height ratios at various ages. Since there is no evidence of a sex difference, both sexes have been combined. The correlation between weight-for-height ratios at age 5 and at age 22 $(r=0 \cdot 35)$ is highly significant; correlations between ratios and birth weight are lower: at 5 years, 0.24 $(\mathrm{P}<0.001)$ for males and $0.19(\mathrm{P}<0.01)$ for females; at 22 years 0.08 (not significant) for males and $0.18(P<0.01)$ for females.

There is some correlation between weight gain from birth to 3 years of age and weight-for-height ratio at age 22 in females. The coefficient, 0.35 , is highly significant and indicates that female babies who gained weight rapidly as infants and toddlers had relatively high weight-for-height ratios at age 22. But this is not true for males, in whom the correlation coefficient was only 0.09 (not significant).

Trends in weight-for-height by social class are erratic and do not reach statistical significance. In males, there is a slight tendency for the taller boys to have lower weight-for-height indices, but in girls there is no association with height.

\section{Age at Menarche}

Age at puberty among the boys was not recorded; in girls, age at menarche was recorded in all but 11 subjects. The median ages at menarche were $13 \cdot 3$,

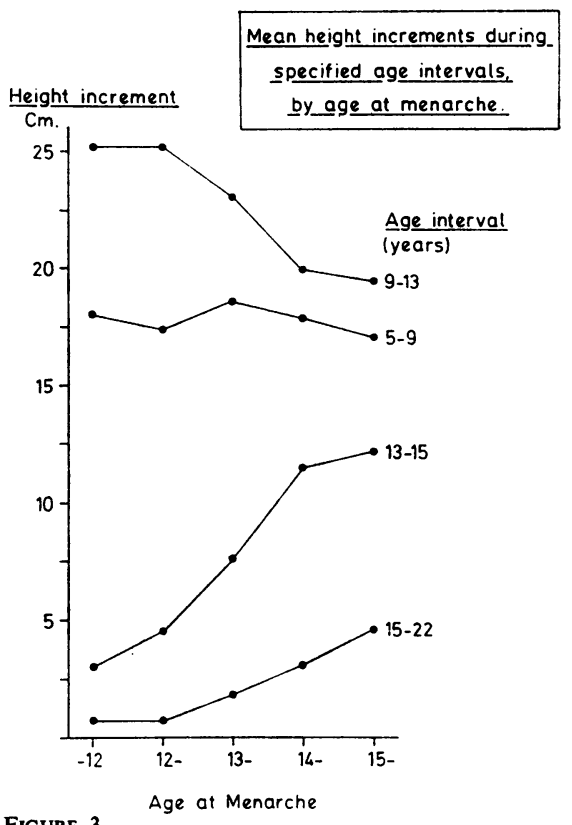

FIGURE 3

$13 \cdot 4$, and $13 \cdot 7$ years for social classes $I+\stackrel{8}{\overrightarrow{9}}$ III, and IV + V, respectively. Overall $11 \%$ of gi (22) had started menstruating by age 11 and $13 \%$ (29) started at age 15 or later.

Table VIII shows mean weights, heights, and weight-for-height indices and mean gains in height between specified ages, according to age at menarche $\frac{\circ}{D}$ At ages 9 and 13 the early maturing girls were taller? and heavier than those who matured late; in othere words, the taller and heavier girls tended to mature earliest. Thereafter the weight differential was maintained, so that at age 22 the early maturing. girls were still the heaviest group; but the heigh历 differential became reversed, so that at age 22 the late maturers formed the tallest group. Figure $3 \frac{0}{3}$ illustrating the increments of height between various ages, may help to make the height patterns? clearer. The amount of height gained between 5 and 9 years does not show a consistent gradient, but gains from age 13 onwards tend to increase steadilyo as the age at menarche increases. The combination of weight and height patterns means, of course, that during and after adolescence the early maturing girls tended to be heavier relative to their height than the late maturing girls; the pattern seems to bes that late maturers become taller and more slendef than early maturers.

\section{Discussion}

The primary aim of the Thousand Families survey was to study morbidity during childhoo 
TABLE VIII

MEAN WEIGHTS, HEIGHTS, AND WEIGHT INDICES BY AGE AT MENARCHE AND MEAN HEIGHT CHANGES FROM 5 YEARS ONWARDS

\begin{tabular}{|c|c|c|c|c|c|c|c|c|c|c|c|}
\hline & \multicolumn{9}{|c|}{ Age } \\
\hline & & & \multicolumn{2}{|c|}{ Birth } & 3 & 5 & 9 & 13 & 14 & 15 & 22 \\
\hline $\begin{array}{c}\text { Age at menarche (yr) } \\
-12=. . \\
12-. . \\
13-. . \\
15-. . \\
15+.\end{array}$ & $\begin{array}{l}. \\
\ddot{y} \\
.\end{array}$ & $\begin{array}{l}. . \\
\ddot{.} \\
. .\end{array}$ & $\begin{array}{l}3 \cdot 07 \\
3 \cdot 25 \\
3 \cdot 35 \\
3 \cdot 27 \\
3 \cdot 33\end{array}$ & $\begin{array}{l}(13) \\
(33) \\
(36) \\
(21) \\
(14)\end{array}$ & $\begin{array}{l}14 \cdot 3 \\
14 \cdot 3 \\
14.5 \\
13.9 \\
14 \cdot 5\end{array}$ & $\begin{array}{l}18 \cdot 5 \\
19 \cdot 1 \\
19 \cdot 3 \\
19 \cdot 1 \\
18 \cdot 4\end{array}$ & $\begin{array}{l}27 \cdot 2 \\
26 \cdot 9 \\
26 \cdot 8 \\
26 \cdot 4 \\
25 \cdot 8\end{array}$ & $\begin{array}{l}47 \cdot 6 \\
46 \cdot 6 \\
43 \cdot 7 \\
38 \cdot 9 \\
37 \cdot 9\end{array}$ & $\begin{array}{l}51 \cdot 3 \\
550.9 \\
49.1 \\
44 \cdot 6 \\
43 \cdot 3\end{array}$ & $\begin{array}{l}51.4 \\
53.4 \\
52.6 \\
50.5 \\
47.5\end{array}$ & $\begin{array}{l}59.8 \\
57.0 \\
56.4 \\
56.2 \\
47.0\end{array}$ \\
\hline $\begin{array}{c}\text { Height (cm) } \\
\text { Age at menarche (yr) } \\
-12 \\
12-. . \\
13-. . \\
14-. . \\
15+. .\end{array}$ & $\begin{array}{l}. . \\
. \\
.\end{array}$ & $\begin{array}{l}. \\
\ddot{.} \\
.\end{array}$ & & & $\begin{array}{l}91 \cdot 2 \\
92 \cdot 3 \\
93 \cdot 4 \\
90 \cdot 9 \\
92 \cdot 2\end{array}$ & $\begin{array}{l}110 \cdot 5 \\
110 \cdot 3 \\
110 \cdot 8 \\
109 \cdot 3 \\
108 \cdot 6\end{array}$ & $\begin{array}{l}128.5 \\
128.2 \\
129.4 \\
127.2 \\
125 \cdot 7\end{array}$ & $\begin{array}{l}153.7 \\
153.4 \\
152.5 \\
147.2 \\
145.2\end{array}$ & $\begin{array}{l}155.2 \\
156.4 \\
157.3 \\
154.5 \\
152.9\end{array}$ & $\begin{array}{l}156.7 \\
158.2 \\
160.1 \\
158.7 \\
157.4\end{array}$ & $\begin{array}{l}157.4 \\
159.4 \\
161.9 \\
161.8 \\
162.0\end{array}$ \\
\hline $\begin{array}{c}\text { Weight-for-height inde } \\
\text { Age at menarche (yr) } \\
-12 . . . \\
12-. . \\
13-. . \\
14-. . \\
15+. .\end{array}$ & $\begin{array}{l}. . \\
\because \\
\because\end{array}$ & $\begin{array}{l}. . \\
\ddot{.} \\
. .\end{array}$ & & & $\begin{array}{l}\bar{z} \\
\bar{z}\end{array}$ & $\begin{array}{l}100 \cdot 0 \\
103.6 \\
104.3 \\
105.9 \\
103 \cdot 3\end{array}$ & $\begin{array}{l}102 \cdot 8 \\
102 \cdot 2 \\
99 \cdot 7 \\
102 \cdot 0 \\
103 \cdot 2\end{array}$ & $\begin{array}{l}108.3 \\
106.8 \\
101.2 \\
99 \cdot 3 \\
100 \cdot 2\end{array}$ & $\begin{array}{r}109 \cdot 6 \\
107.4 \\
101.4 \\
96.4 \\
95.8\end{array}$ & $\begin{array}{l}104.3 \\
106.6 \\
102.4 \\
99.8 \\
95.6\end{array}$ & $\begin{array}{l}114.6 \\
107.7 \\
103.6 \\
103.4 \\
104 \cdot 3\end{array}$ \\
\hline $\begin{array}{c}\text { Mean height }(\mathrm{cm}) \\
\text { change from } 5 \mathrm{yr} \text { up } \\
-12 \\
12-. . \\
13-. . \\
14-. . \\
15+. .\end{array}$ & $\begin{array}{l}\because \\
\because \\
\because \\
\ddot{n}\end{array}$ & $\begin{array}{l}\because \\
\because \\
\because \\
\therefore\end{array}$ & & $\begin{array}{l}\because \\
\because \\
\because \\
\because\end{array}$ & $\begin{array}{l}.^{\text {years }} \\
\because \\
\because \\
.\end{array}$ & $\begin{array}{l}5-9 \\
18 \cdot 0 \\
17 \cdot 4 \\
18 \cdot 6 \\
17 \cdot 9 \\
17 \cdot 1\end{array}$ & $\begin{array}{l}9-13 \\
25 \cdot 2 \\
25 \cdot 2 \\
23 \cdot 1 \\
20 \cdot 0 \\
19 \cdot 5\end{array}$ & $\begin{array}{r}13-14 \\
1.5 \\
3 \cdot 0 \\
4.8 \\
7.3 \\
7.7\end{array}$ & $\begin{array}{r}14-15 \\
1.5 \\
1.8 \\
2.8 \\
4.2 \\
4.5\end{array}$ & $\begin{array}{r}15-22 \\
0.7 \\
1.2 \\
1.8 \\
3.1 \\
4.6\end{array}$ & \\
\hline
\end{tabular}

and the anthropometric data are probably less precise than could be wished. There is, however, no reason to suspect that the measurements were biassed, and although errors and losses of subjects over 22 years may have obscured some relationships that would otherwise have been apparent, it is unlikely that they created trends that did not exist. Four points of special interest have emerged from the analysis.

The first is the absence of a social class gradient in height among older females, whereas such a gradient was present in males (Table IV). This is probably due to the use of the occupation of the subjects' parents as the basis of our social classification. Illsley (1955) has shown that in married primigravidae this results in a greatly attenuated gradient in height compared with that obtained when the social classification is based on the subjects' own occupations before marriage or that of their husbands. Relatively few of the females in the present survey were in professional occupations or married husbands in the professional class; we could therefore afford only a division into nonmanual and manual categories. The average height of 162 women in non-manual jobs was $161.0 \mathrm{~cm}$, compared with $158.9 \mathrm{~cm}$ for 77 women in manual occupations. Similarly, 28 women married to men in white collar jobs had a mean height of
$160.9 \mathrm{~cm}$, while 93 with husbands in manual jobs averaged $159.3 \mathrm{~cm}$. The divergence of the result shown in Table IV from that to be expected from reports in the obstetric literature is more apparent than real.

The second feature of interest is the correlation of weight and height at various ages with birth weight (Table VI, Figures 1 and 2). This relationship has been demonstrated by Illingworth, Harvey, and Gin (1949) and Illingworth (1950) in children up to ages 12-13 but may not have been shown previously for adults. It appears that the final size attained is to a small extent determined by size at birth, possibly further confirmation that impairment of growth at the earliest stages may have permanent effects.

Thirdly, there are correlations between weightfor-height ratios at various ages; note particularly the highly significant correlation $(0 \cdot 35)$ between the ratios at 5 years and at 22 years of age. This particular correlation shows no sex difference but there is a higher correlation in females than in males between weight-for-height ratios at age 22 years and birth weight $(0.18$ and 0.08 for females and males, respectively). Similarly, the correlation of weight-for-height ratios at 22 years with weight gained from birth to 3 years of age is 0.35 for females and 0.09 for males. In both instances, the 
correlations for females are statistically significant, and in the second instance the correlation for females is significantly higher than that for males $(P<0.05)$. Early gains in weight may, therefore, have a greater effect on weight-for-height in early adult life in females than in males.

Finally, patterns of gains in height in relation to age at menarche (Table VIII and Figure 3) confirm the results of Shuttleworth (1939) and Kantero and Widholm (1971). The early-menarche girls are taller and heavier at 9 years; at 22 years, however, the late maturers are taller while the weight difference in favour of the early maturers persists. Thus in young adulthood the early maturing girls have, on average, higher weight-for-height ratios than late maturers. It appears that, in girls at least, rapid growth may lead to earlier maturation and attainment of adult size, thus diminishing the differentials of height that are apparent before puberty.

\section{SUMMARY}

Two hundred and one males and 241 females, born in May or June 1947 and observed in the course of the 'Thousand Families in Newcastle upon Tyne' study, have been traced and measured at the age of 22 years. A significant degree of correlation between birth weight and subsequent body size has been observed; at the age of 22 years the correlation coefficients with birth weight were 0.25 and 0.26 for weight and height, respectively.

Examination of weight-for-height ratios showed a significant correlation $(0.35)$ between ratios at 5 and at 22 years. There was a significant correlation of weight-for-height ratios at 22 years with the amount of weight gained from birth to 3 years of age for females $(0.35)$ but not for males (0.09); the two correlations are significantly different $(P<0.05)$.

Girls reaching the menarche at a relatively early age were taller and heavier at age 9 than those who matured later, and were also heavier at age 22. Girls who matured later were, however, taller at age 22 .
We wish to thank the Medical Research Council for the grant which made the work possible; Dr. D. L. Wilson, Medical Officer of Health for Newcastle upon Tyne; Miss F. E. Hunt, Director of Nursing Services, Newcastle upon Tyne; and Miss A. C. Emerson, Nursing Officer. Evening visits were made by the following members of the staff of the Health Department of Newcastle upon Tyne: Health Visitors-Miss M. E. Alderson, Mrs. E. M. Caughey, Miss T. Chesterton, Mrs. M. Cogle, Miss I. Harris, Miss L. R. Johnstone, Mrs. M. Pattison, Mrs. M. S. Pattison, Mrs. M. R. Richardson, and Miss P. M. Riley. Secretarial work was carried out by Mrs. B. Storey and Mrs. L. Jopling. Miss R. M. Holliday gave valuable assistance with the analyses of data.

We would also like to thank the Editor and Staff of the Newcastle Evening Chronicle for their assistance with publicity.

\section{REFERENCES}

ILLINGWORTH, R. S. (1950). Birth weight and subsequent weight. Brit. med. J., 1, 96.

-, HaRVEY, C. C., and Gin, S-Y. (1949). Relation of birth weight to physical devleopment in childhood. Lancet, 2, 598.

ILlSLEY, R. (1955). Social class selection and class differences in relation to stillbirths and infant deaths, Brit. med. J., 2, 1520.

INTERDEPARTMENTAL COMMITTEE ON NUTRITION FO National Defense (1963). Manual for Nutritiō̄ Surveys, 2nd ed. National Institutes of Health? Bethesda, Md.

KANTERO, R., and Widholm, O. (1971). The age of menarche of Finnish girls in 1969. Acta obstet. Gynec. scand., Suppl., 14, 7.

Kemsley, W. F. F., Billewicz, W. Z., and Thomson, A. M. (1962). A new weight-for-height standard based on British anthropometric data. Brit. J. prev. soc. Med., 16, 189.

Miller, F. J. W., Court, S. D. M., Walton, W. S., and KNOX, E. G. (1960). Growing up in Newcastle upon Tyne. Oxford University Press, London.

ShutTlewORTH, F. K. (1939). The physical and mental growth of girls and boys age six to nineteen in relation to age at maximum growth. Monogr. Soc. res. child. Developm., Vol. 4, No. 3., p. 291.

Spence, J., Walton, W. S., Miller, F. J. W., and CourT, S. D. M. (1954). A Thousand Families in Newcastle upon Tyne. Oxford University Press, London. 